\title{
Evaluation of the Impact of the EU Structural Support on the Competitiveness of Lithuanian Economics
}

\begin{abstract}
The topic of competitiveness is becoming increasingly significant in the context of modern economics. Considering intensive processes of globalisation alongside with competitive pressure amongst the countries, competitiveness has become a necessary condition for successful economic and social development of any country. Only by creating, enforcing and maintaining international competitiveness of the country, rapid economic growth during the long term is achievable. Amongst the other urgent issues, the European Union (further the EU) public policies are also focused on competitiveness. After the failure to implement the Lisbon strategy and become "the most dynamic and competitive knowledge-based economy", the EU declared its new competitiveness aims in the long-term strategy Europe 2020. Promotion of competitiveness is one of the fundamental aims and priority directions of the EU structural policy. The EU structural support is engaged as one of the public policy measures to promote the competitiveness of the member-states. In this context, it is purposeful to research whether the structural support is used efficiently and whether it actually contributes to the implementation of the defined aims. Under the order of various Lithuanian institutions, numerous studies on the efficiency of the EU structural support have been carried out. Nevertheless, by analysing the impact of the EU structural support, insufficient attention has been paid to the aspect of competitiveness. Considering the fact that Lithuania has entered the third programming period 2014-2020, evaluation of the EU structural investment in the country has become even more topical - for successful implementation of the aims raised for this new period, the analysis of the previous results is relevant. This determined formulation of the research problem: what impact does the EU structural support have on the competitiveness of Lithuanian economics? The empirical research has revealed that the EU structural support has a positive impact on Lithuanian gross domestic product growth, promotes foreign direct investment, research and development expenditure and increases the number of operating entities during 2004-2014 period.
\end{abstract}

KEYWORDS: competitiveness, the EU structural support, Lithuanian economics, the impact of the EU structural support

RECEIVED 14 July 2015; ACCEPTED 29 January 2016.

\section{INTRODUCTION}

The European Union (the EU) cohesion policy is aimed at contribution to economic growth and increase of competitiveness by promoting economic, social and territorial cohesion, sustainable development of the EU regions. The analysis of the scientific literature (Aiello \& Pupo 2012, Cardenete \& Delgado 2013, Dall'Erba, Guillain \& Le Gallo 2009, Fiaschi, Lavezzi \& Parenti 2011, Lithuanian Free Market Institute 2011, Mohl \& Hagen 2010, Mosionek-Schweda \& Tokarski 2014, Paun 2013, Puigcerve-Penalver 2004, Varga \& Veld 2010, Žalevičiene 2012 and others) has revealed that the impact of the EU structural support is analysed in various aspects, and the results of the research are rather different. The benefit of the EU structural support is described by its positive impact on economic development, which reveals itself with the increased investment in Research and Development (further R\&D) and innovations, new products and production methods, infrastructure improvement, expansion of production capacities and specialization, improvement of human resources, reduction of unemployment rate and promotion of business development. Income distribution inequalities, determining internal competition distortions, private investment flush out, inflation pressure, and so on, are considered to be the negative outcomes of the structural support. The above-mentioned negative outcomes are basically determined by inefficient distribution and absorption of the support funds. It should be noted that in particular studies, structural funding is treated as the one not having any significant impact on the economics of the country. In Lithuania, by the order of different

1 Rita Remeikiene, Ligita Gaspareniene: Mykolas Romeris University, Ateities str. 20, Vilnius. Email: rita.remeikiene@mruni.eu; ligitagaspareniene@mruni.eu. 
institutions, numerous evaluations of the EU structural support absorption have been performed. Basically, general issues, topical for all industries, as well as the problems of the support administration system have been tackled. Nevertheless, by researching the impact of the structural support, efficiency of separate programming periods rather than the aspects of the competitiveness of Lithuanian economics is analysed. Considering the fact that Lithuania has entered the third programming period of 2014-2020, evaluation of the EU structural investment in the country has become even more topical - for successful implementation of the aims raised for this new period, the analysis of the previous results is relevant. This determined the formulation of the research problem: what impact does the EU structural support have on the competitiveness of Lithuanian economics? The object of the research is the impact of the EU structural support on the competitiveness of Lithuanian economics. The purpose of the research is to evaluate the impact of the EU structural support on the competitiveness of Lithuanian economics.

The defined purpose has been detailed into the following objectives:

1. To perform the analysis of the scientific literature on the impact of public funds on the competitiveness of the support-absorbing countries;

2. To substantiate selection of the method, used for empirical estimations;

3. To carry out the empirical research for the evaluation of the impact of the EU structural support on the competitiveness of Lithuanian economics.

The methods of the research include literature analysis, statistical data analysis and assessment and simple correlation (Pearson coefficient).

\section{THE IMPACT OF PUBLIC FUNDS ON THE COMPETITIVENESS OF THE SUPPORT- ABSORBING COUNTRIES: THEORETICAL ASPECTS}

Country's competitiveness refers to its ability to form favourable conditions for business development and successful sales of products and services in both domestic and international markets, alongside ensuring the improvement in population's employment and life standards (Navickas 2010). Competitiveness of sectors and companies is considered to be a foundation of national competitiveness. Thus, it is extremely important to ensure competitiveness in all of its levels. The concept of competitiveness is better comprehended following the results of the research on the determinants of competitiveness.

Consideration of the main aim of the EU cohesion policy (contribution to economic growth and increase of competitiveness by promoting economic, social, territorial cohesion and sustainable development of the member-states) proposes that international competitiveness of any country, which absorbs the support from public funds, such as the EU structural funds, is a complex of numerous structural components. Gherghinescu, Kolodziejak, and Gherghinescu (2008) highlighted two aspects of the EU competitiveness: endogenic potential of competitiveness (absolute competitiveness), determined by the EU and its member-states investment, scientific research, innovation, development of human and physical capital and so on, and exogenic potential of competitiveness (comparative competitiveness), determined by the interrelated European and international development that involves the fields of international trade, finance and investment. The impact of the support from the public funds on competitiveness can be evaluated by considering various aspects: macroeconomic (Lithuanian Free Market Institute 2011, Paun 2013, Varga \& Veld 2010), regional (Aiello \& Pupo 2012, Becker, Egger \& Ehrlich 2010, Mohl \& Hagen 2010) and so on.

The performed analysis of the scientific literature has revealed that public funds, such as the EU structural funds, might have an ambiguous impact on the competitiveness of the support-absorbing countries. Some scientists (Cardenete \& Delgado 2013, Puigcerve-Penalver 2004, Varga \& Veld 2010) note and empirically substantiate positive effects of the public funds (basically-the EU structural funds) on the competitiveness of the analysed countries, whereas others find these effects weak (Aiello \& Pupo, 2012, Dall'Erba et al. 2009, Žalevičienė 2012), statistically insignificant (Aiello \& Pupo 2012) or even negative (Dall'Erba et al. 2009, Fiaschi et al. 2011). A part of the authors (Mohl \& Hagen 2010, Paun 2013, etc.) find the effects bidirectional - positive in particular sphere, and insignificant or negative in other fields. The analysis of the scientific literature has enabled to identify positive, negative and insignificant potential impact of public funds (basically- the EU structural funds) on the determinants of the competitiveness of the support-absorbing countries (see Table 1). 
Tab. 1: The potential impact of public funds on the determinants of competitiveness

\begin{tabular}{|c|c|c|c|c|c|c|}
\hline Determinants & & Positive impact & & Negative impact & & Insignificant impact \\
\hline $\begin{array}{l}\text { Infrastructure } \\
\text { determinants }\end{array}$ & 2) & $\begin{array}{l}\text { Transport infrastructure } \\
\text { improvement (Dumčiuvienė \& } \\
\text { Adomynienė 2014) } \\
\text { Internet connection spread } \\
\text { (Dumčiuvienė \& Adomynienè 2014) }\end{array}$ & & - & 1) & $\begin{array}{l}\text { Insignificant impact } \\
\text { on infrastructure } \\
\text { (Pose \& Fratesi 2004) }\end{array}$ \\
\hline $\begin{array}{l}\text { Macroeconomic } \\
\text { determinants }\end{array}$ & 5) & $\begin{array}{l}\text { Gross domestic product (further } \\
\text { GDP) growth (Dumčiuvienė \& } \\
\text { Adomynienè 2014, Mohl \& Hagen } \\
\text { 2010, Paun 2013, SSE Riga University } \\
\text { 2011) } \\
\text { Motivation of enterprises to } \\
\text { operate in business (Dumčiuvienė } \\
\text { \& Adomynienè 2014, Mosionek- } \\
\text { Schweda \& Tokarski 2014) } \\
\text { Promotion of foreign direct } \\
\text { investment (Dumčiuvienė \& } \\
\text { Adomyniene 2014, Mosionek- } \\
\text { Schweda \& Tokarski 2014) } \\
\text { R\&D expenditure increase (Paun } \\
\text { 2013, Varga \& Veld 2010) } \\
\text { Export promotion (Mosionek- } \\
\text { Schweda \& Tokarski 2014, Paun } \\
\text { 2013) } \\
\text { Unemployment reduction (Enguix, } \\
\text { Garcia \& Gallego 2012, Mosionek- } \\
\text { Schweda \& Tokarski 2014) }\end{array}$ & 6) & $\begin{array}{l}\text { Increase in unemployment rate } \\
\text { (Paun 2013) } \\
\text { Impeded export of high technology } \\
\text { products (Paun 2013) } \\
\text { Expensive investment } \\
\text { (Lewandowska, Stopa \& Humenny } \\
\text { 2014) } \\
\text { Limited impact on consumer prices } \\
\text { (SSE Riga University 2011) } \\
\text { Negative impact on other (support } \\
\text { not absorbing) economic sectors } \\
\text { and companies (Balzaravičienė \& } \\
\text { Pilinkienè 2012, Katsaitis \& Doulos } \\
\text { 2009, Mohl \& Hagen 2010, SSE } \\
\text { Riga University 2011) } \\
\text { Poor contribution to regional } \\
\text { competitiveness (Žalevičienė 2012) } \\
\text { Raise of inflation pressure (Varga \& } \\
\text { Veld 2010) } \\
\text { Distorted budget balance } \\
\text { (Balzaravičienė \& Pilinkienè 2012) }\end{array}$ & 1) & $\begin{array}{l}\text { Weak link between } \\
\text { GDP per capita and } \\
\text { the support amount } \\
\text { (Aiello \& Pupo 2012) } \\
\text { Insignificant impact } \\
\text { on unemployment } \\
\text { (Becker et al. 2010, } \\
\text { Mohl \& Hagen 2010) }\end{array}$ \\
\hline $\begin{array}{l}\text { Social } \\
\text { determinants }\end{array}$ & 1) & $\begin{array}{l}\text { Development of human resources } \\
\text { (Dumčiuvienė \& Adomynienè 2014, } \\
\text { Paun 2013, Pose \& Fratesi 2004) }\end{array}$ & 1) & $\begin{array}{l}\text { Inequalities of income distribution } \\
\text { (Katsaitis \& Doulos 2009, Paun } \\
\text { 2013) }\end{array}$ & & - \\
\hline $\begin{array}{l}\text { Production } \\
\text { determinants }\end{array}$ & 5) & $\begin{array}{l}\text { Promotion of innovations } \\
\text { (Dumčiuvienė \& Adomynienè 2014, } \\
\text { Mosionek-Schweda \& Tokarski 2014) } \\
\text { Promotion of new products and } \\
\text { production methods (Dumčiuvienè } \\
\text { \& Adomynienė 2014, Enguix et al. } \\
\text { 2012) } \\
\text { Usage of energy-efficient resources } \\
\text { (Dumčiuvienè \& Adomynienè 2014) } \\
\text { Increased labour productivity (SSE } \\
\text { Riga University 2011) } \\
\text { Industrial development (Mosionek- } \\
\text { Schweda \& Tokarski 2014) } \\
\text { Production capacity growth (Varga \& } \\
\text { Veld 2010) }\end{array}$ & 1) & $\begin{array}{l}\text { Dependence on the knowledge of } \\
\text { large conglomerates (Mosionek- } \\
\text { Schweda \& Tokarski 2014) }\end{array}$ & 2) & $\begin{array}{l}\text { Insignificant impact } \\
\text { on labour productivity } \\
\text { (Aiello \& Pupo 2012) }\end{array}$ \\
\hline $\begin{array}{l}\text { Institutional } \\
\text { determinants }\end{array}$ & & - & 1) & $\begin{array}{l}\text { Contribution only to the countries } \\
\text { with high institutional efficiency } \\
\text { (Katsaitis \& Doulos 2009) }\end{array}$ & & - \\
\hline
\end{tabular}

Source: compiled by the authors 
As it can be seen in Table 1, the potential impact of public funds on the competitiveness of the support-absorbing countries is basically determined by infrastructure, macroeconomic, social, production and institutional determinants. With reference to Dumčiuvienè and Adomynienè (2014), positive effects of the EU structural support reveal themselves by positive changes in infrastructure, such as transport infrastructure and Internet connection improvement. However, Pose and Fratesi (2004) established insignificant impact of the structural funds on infrastructure and business.

The analysis of macroeconomic determinants have earned rather sufficient scientific attention. Dumčiuvienė and Adomynienė (2014) highlighted the promotional effects of the support on motivation of small and medium enterprises to operate in business (particularly in cost inefficient sectors) and favourable conditions for foreign direct investment (FDI). The research carried out by Paun (2013) also revealed that public funds can have positive effects on gross domestic product (GDP) growth, R\&D expenditure increase as well as promotion (although slight) of the country's export share in global export. The author also observes some negative effects of the support - it might determine the increase in unemployment rate (higher level of support absorption might determine higher unemployment rate), inequalities of income distribution and impedes the export of high technology products. The research performed by SSE Riga University (2011) revealed positive effects of the EU funds on GDP growth. Nevertheless, the impact of public funds on consumer prices was found to be limited. What is more, it is noted that investment in one sector might negatively (although indirectly) affect other sectors in the long term. Aiello and Pupo (2012) found the potential impact of public funds on competitiveness invisible or insignificant - according to them, the link between GDP per capita and the amount of the support provided for particular region is weak. Nevertheless, it is important to note that the results of the research not necessarily reflect the real impact of the support from public funds - economic growth might be determined by other factors - both promotional and restrictive. According to Žalevičienè (2012), public funds do not contribute to regional competitiveness (on the other hand, the research covered only the changes in regional competitiveness excluding the absorbed structural support as a determinant of competitiveness). Mosionek-Schweda and Tokarski (2014) established the benefits of the EU structural funds on business development - according to them, the support determines rapid investment as well as purchase and use of the advanced technologies, which could not be purchased by business enterprises without the support from the public funds. What is more, public funding contributes to the creation of new work places and unemployment reduction alongside with its positive effects on companies' development and increase in their competitiveness in international markets. Thus, public funding helps companies to become more innovative and gain competitive advantage.

It is also important to note that the impact of public funds on the competitiveness of the support-absorbing countries largely depends on the aim of funding (Mohl \& Hagen 2010). It was established that economic growth is promoted by the projects that are funded following the first strategic priority (convergence) of the EU structural funds (Becker et al. 2010, Fiaschi et al. 2011, Mohl \& Hagen 2010), whereas neither funding of second (regional competitiveness and employment) or third (priority of European territorial co-operation) priorities nor overall structural support has any statistically significant impact on economic growth (Mohl \& Hagen 2010) or this impact is negative (Fiaschi et al. 2011). Employment, in contrast to GDP, is not affected by the structural support allocated following the first priority. Such results are caused by the two factors: first, funding based on the first priority basically promotes the volumes and structural changes of investment; second, creation of work places generally takes longer than the programming period (Becker et al 2010). Enguix et al. (2012) argued that the basic part of the regions of the first priority are oriented to unemployment rate reduction. The authors also noted that the regions, which modernise production structure by developing highproductivity sectors, are able to achieve better results in both productivity and employment fields.

In the group of social determinants, education and skills training as well as improvement of human resources are highlighted as the determinants that have the most significant potential impact of public funds on support-absorbing countries (Dumčiuviene \& Adomynienè 2014, Paun 2013). However, income distribution inequality is pointed out as the basic negative determinant in this group. According to Katsaitis and Doulos (2009), although public funds facilitate the competition for the companies that absorb the support, it burdens the competition for the other companies that do not receive the funding. As it was stressed by Balzaravičiene and Pilinkienè (2012), despite the general aims of growth, development and competitiveness increase, structural support is allocated unequally for different industries, which distorts the market and raises the threat of inefficient distribution of the national budget funds that are used for the support of the projects.

In the group of production determinants, the scientists highlight positive impact of the public funds on the promotion of innovations, new products and production methods and usage of energy-efficient resources (Dumčiuvienè \& Adomynienè 2014). The 
significant contribution to labour productivity is also acknowledged (Aiello \& Pupo 2012, SSE Riga University 2011). According to Mosionek-Schweda and Tokarski (2014), investment in internal inventions as well as implementation of new solution in production are the fundamental determinants for innovation development because only in this way, companies can gain competitive advantage and offer their products for higher price in both domestic and foreign markets. On the other hand, it is stated that the public funds might cause negative effects on production determinants if the support is concentrated on faster but not more qualitative and efficient absorption (Dumčiuvienè \& Adomynienè 2014). In addition, with reference to Mosionek-Schweda and Tokarski (2014), by absorbing public funds, companies simply apply the innovative decisions of big corporations from advanced countries. This way they not only become dependent on the knowledge of large conglomerates but also actually promote the development of industrial economies.

Finally, considering the impact of public funds on institutional determinants of competitiveness, Katsaitis and Doulos (2009) noted that structural support determines competitive advantage in the countries with high institutional efficiency, whereas for the countries with low institutional efficiency, the impact of the support might be negative.

It should also be noted that the impact of the structural support varies in the short and long terms. As it was established by Varga and Veld (2010), during the short term, structural support determines growth of expenditure and production capacities; on the other hand, it also raises inflation pressure, may determine the rise of real value and may flush out private investment. During the long term, support funds promote productivity - investment in infrastructure and human capital as well as R\&D expenditure gradually increases. As it was pointed out by Becker et al. (2012), structural support is, in general, efficient only up to a particular point, where the return on funds starts to decrease and extra funding does not determine extra growth.

In spite of the variety of the determinants of competitiveness, this research is focused on the analysis of the impact of the EU structural funds, as public funds, on macroeconomic determinants of country's competitiveness because, according to Lewandowska et al. (2014), macroeconomic factors serve as an important factor of state statistics and external competitiveness of the country. Thus, they contribute not only to business development but also to the modernisation of regional economics, basically increasing the volumes of investment, the flows of new technologies, production capacities, specialisation and management efficiency.

\section{THE METHODOLOGY OF THE EMPIRICAL RESEARCH ON THE IMPACT OF THE EU STRUCTURAL SUPPORT ON THE COMPETITIVENESS OF LITHUANIAN ECONOMICS}

Competitiveness of the country is determined by numerous factors, which can be divided into micro- and macroeconomic, internal and external and so on. Whilst performing the analysis of the competitiveness of the countries, macroeconomic factors, which reveal the overall economic situation of the country, are traditionally considered to be the most significant. However, in the contemporary context, such assessment is insufficient; the factors of scientific and technological infrastructure such as information technology (IT) and telecommunication accessibility, innovations and human resources must also be considered. For an adequate evaluation of country's competitiveness, it is necessary to engage all factor groups and follow a complex approach without giving any priorities to one or another factor.

The research is aimed at the establishment of the impact of the EU structural support, absorbed by Lithuania, on the main quantitative economic factors that determine the competitiveness of the country.

The research consists of statistical data review of the macroeconomic factors that determine the competitiveness of Lithuanian economics and the absorbed the EU structural support and simple correlation. Correlation is a technique for investigating the relationship between two quantitative, continuous variables. Pearson's correlation coefficient $(r)$ is a measure of the strength of the association between the two variables (dependent and independent variables). Pearson $r$ correlation is widely used in statistics to measure the degree of the relationship between linear-related variables. For example, in the particular market, if we want to measure how two factors are related to each other, Pearson $r$ correlation is used to measure the degree of relationship between the two factors. For the empirical part of the research, correlation technique was selected in order to establish the existing links between the EU structural support (independent variable) and the indicators that reflect the competitiveness of Lithuania (dependent variables), such as GDP, R\&D expenditure rate, FDI, the number of operating entities, budget balance, annual inflation, employment rate, consumer price index (CPI) and foreign trade balance. The other available statistical methods were rejected because of the following reasons: 
- linear regression model was rejected because of the insufficiently large number of variables. Estimations were based on 11 variables (annual statistical data for the period of country's membership in the EU); monthly or quarterly statistical data was unavailable;

- performance of causality test was rejected because of the insufficiently small number of dynamic line variables, as it the case of linear regression model.

Only statistically significant correlations between the volumes of the EU structural support and selected variables have been introduced in the empirical part of the research, presented in the further section of this article.

\section{THE RESULTS OF THE EMPIRICAL RESEARCH ON THE IMPACT OF THE EU STRUCTURAL SUPPORT ON THE COMPETITIVENESS OF LITHUANIAN ECONOMICS}

GDP is one of the indicators most widely used for the description of country's economics; it enables to evaluate country's economic state and growth. The significance of this indicator determines the necessity to disclose the links between GDP and the EU structural support.

The dynamics of Lithuanian GDP and the volumes of the EU structural support during the period 2004-2014 have been presented in Figure 1.

Fig. 1: The dynamics of Lithuanian GDP and the volumes of the EU structural support during the period 2004-2014

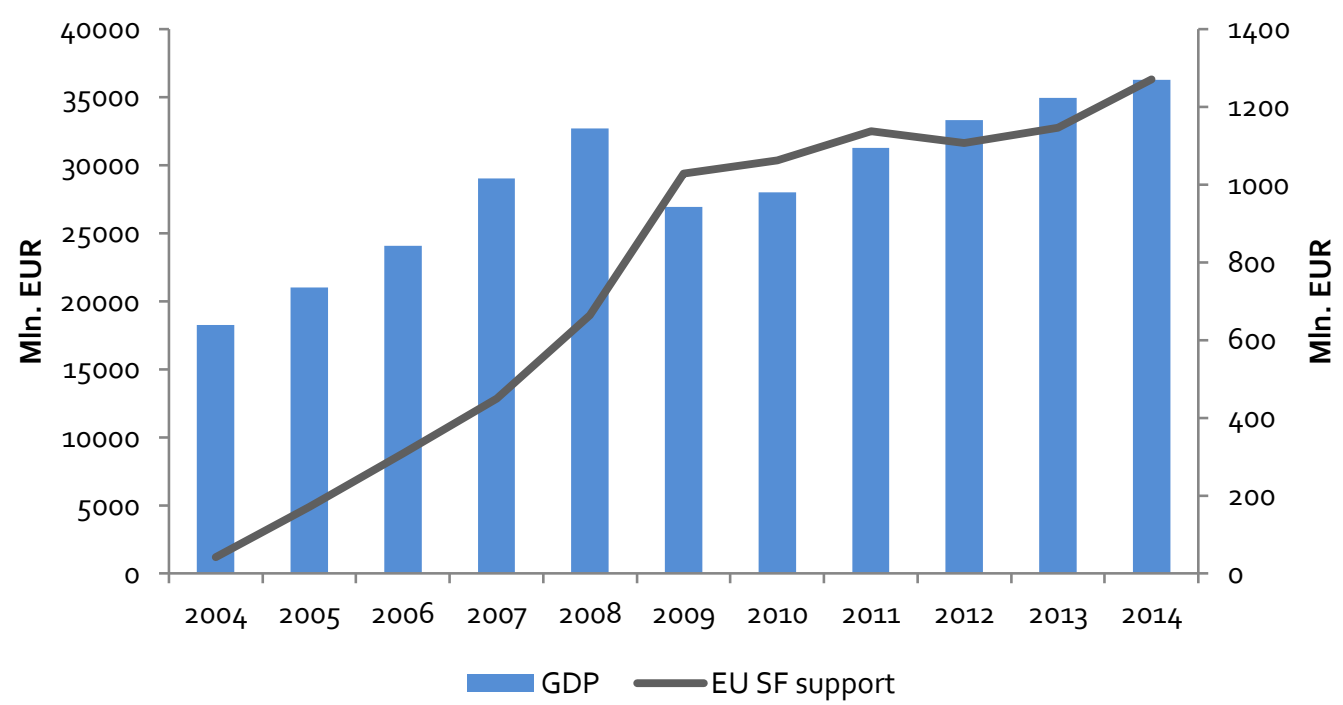

Source: compiled by the authors with reference to the data of Lithuanian Department of Statistics andThe Ministry of Finance of the Republic of Lithuania

During the period 2004-2014, Lithuanian GDP (in current prices) almost doubled, that is, GDP growth during the analysed period reached 98 percent. The graph shows that the changes of Lithuanian GDP during the researched period can be attributed to two main stages: the stage of 2004-2008 and the stage of 2009-2014. The stage of 2004-2008 shows smooth growth of both GDP and the EU structural support. Rather slow but also smooth growth of both indicators can be observed in the stage of 2009-2014, which proposes that the EU structural support had a positive impact on country's GDP during the researched period. It is important to note that GDP, similar to the other economic indicators, is influenced not only by the volumes of structural support but also by numerous factors, for instance, economic cycles or global economic crises, one of which determined GDP decline in Lithuania in 2009 and significantly slowed down its growth till 2014.

The links between the EU structural support and GDP are highlighted in many sources of the scientific literature. With reference to The Assessment of the Impact of the EU Structural Funds on the Economics of the Country and the Prognoses of Economic Growth by 2020 
(2014), performed by the order of the Ministry of Finance of the Republic of Lithuania, Lithuanian GDP grew by 1.57 percent faster during the period 2004-2013 because of the impact of the EU structural support, that is, GDP growth without the EU structural support would have reached only 2 percent instead of 3.57 percent. Thus, it can be concluded that the rapid growth of GDP could have been determined by the introduced measures of finance engineering, which enable a relative decrease in investment costs and indirectly promote larger private investment. It should also be noted that a big share ( 57 percent) of the EU structural support, absorbed by Lithuania during the period 2007-2013, was used for the funding of construction and construction-related works. However, the investment of this kind has only a short-term impact, whereas the long-term impact of the EU structural support emerges via the improvements of the overall economic infrastructure, development of human resources and R\&D because such investment increases competitiveness and productivity and so determines a continual benefit, that is, its impact on GDP persists for some time after the financial investment.

Whilst analysing the links between GDP and the EU structural support, it is important to note that it is bilateral, that is, because one of the priorities of the EU support provision is reduction of the gaps amongst the member states (GDP rate equalisation), the volumes of the provided support also depend on the country's GDP rate. Lithuania is provided with the EU structural support (from European Fund for Regional Development (EFRD) and European Social Fund (ESF)) following one of the aims of convergence by which funding is provided for the regions with GDP per capita lower than 75 percent of Community average (NUTS-2 level regions). In addition, another part of the funding is provided following the first aim, that is, contributions are provided to the member states with GDP per capita lower than 90 percent of the EU average (the support is distributed by the Cohesion Fund).

Calculations of Pearson correlation coefficient, estimated to determine the strength of the links between GDP and the EU structural support, revealed that the value of $r$ is equal to 0.703 and $\mathrm{p}$ is equal to 0.016 , which proposes that the links between GDP and the EU structural support are medium strong positive.

The analysis of the scientific literature has revealed that FDI is one of the most significant determinants of country's competitiveness, emerging as the promotion of new technologies and innovations, spread of management skills, direct capital increase and so on. The impact of the structural support on FDI inflows is highlighted in numerous scientific sources, basically through the development of industrial areas (the support for the development of industrial areas was provided following the regulations of the General Programming Document for 2004-2006 and the Second Action Programme of the EU Structural Support for 2007-2013). It is obvious that the EU structural support and FDI inflows are interrelated; thus, it is purposeful to research to what extent the structural support contributes to the dynamics of FDI. The dynamics of FDI and the EU structural support in Lithuania during the period 2004-2014 has been presented in Figure 2.

Fig. 2: The dynamics of FDI and the volumes of the EU structural support during the period 2004-2014

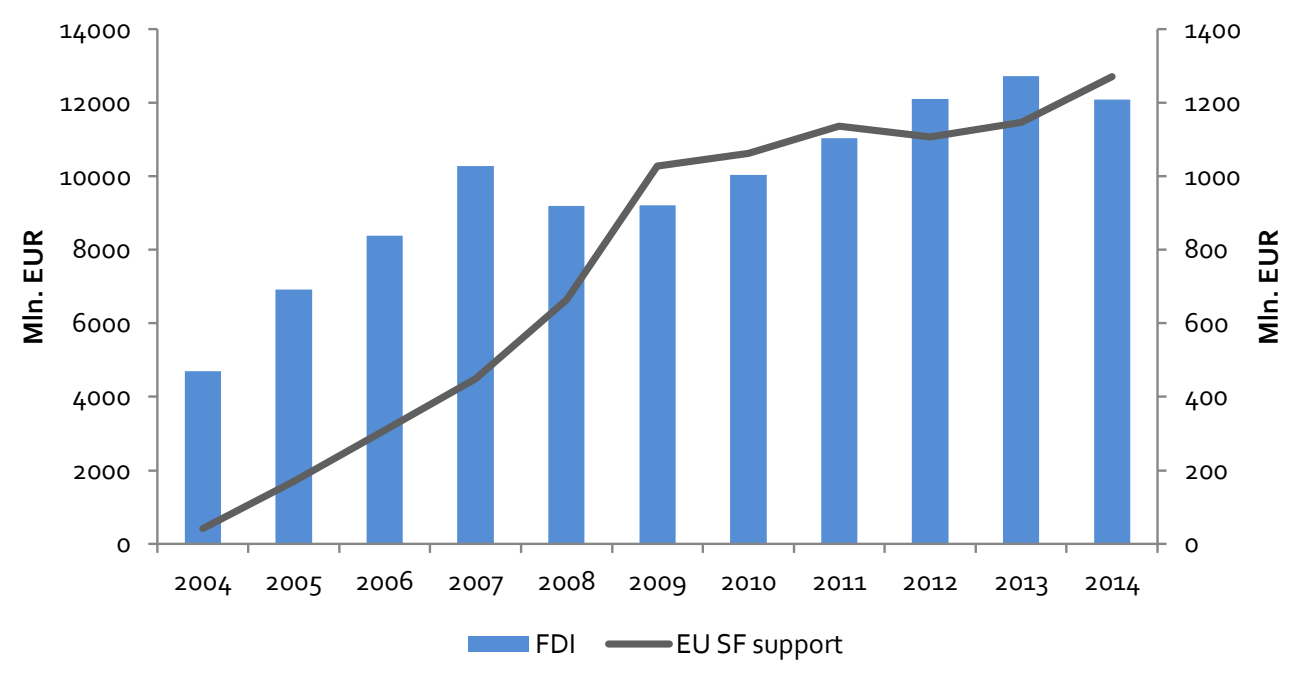

Source: compiled by the authors with reference to the data of Lithuanian Department of Statistics andThe Ministry of Finance of the Republic of Lithuania 
Figure 2 reveals the general (although uneven) trend of FDI growth. However, it should be noted that FDI growth might have been influenced not only by the structural support but also by the integration in the EU, which, as well as structural funding, started in 2004 after Lithuania joined the EU. Calculations of Pearson correlation coefficient, estimated to determine the strength of the links between FDI and the EU structural support, revealed that the value of $r$ is equal to 0.844 and p is equal to 0.001 , which proposes that the links between FDI and the EU structural support are strong positive, that is, increasing inflows of the EU structural support in Lithuania contribute to the growth of FDI.

Scientific research, technologies and innovations are the drives of country's economic growth and competitiveness. For this reason, the EU support programmes include a wide variety of the measures for promotion of this field. During the period 2007-2013, R\&D was the focus of the Human Resources Development Action Programme (aimed at the improvement of the quality of human resources in R\&D sphere and the increase in Lithuanian R\&D capacity and potential) and the Economic Growth Action Programme (aimed at the reinforcement of Lithuanian R\&D base, promotion of R\&D efficiency in the public sector, etc.). With reference to the data of the Ministry of Finance of the Republic of Lithuania (2014), during the period 2007-2013, more than 2,600 subsidies were provided for R\&D activities performed by students, scientists and other researchers; more than 2,400 companies received funding for innovation. This trend is also observed in the Structural Funds Action Programme for 2014-2020, thus, it is purposeful to research the link between the EU structural support and R\&D expenditure rate. The dynamics of the R\&D expenditure rate and the EU structural support in Lithuania during the period 2004-2014 has been presented in Figure 3.

Fig. 3: The dynamics of the volumes of the EU structural support and R\&D expenditure rate during the period 2004-2014

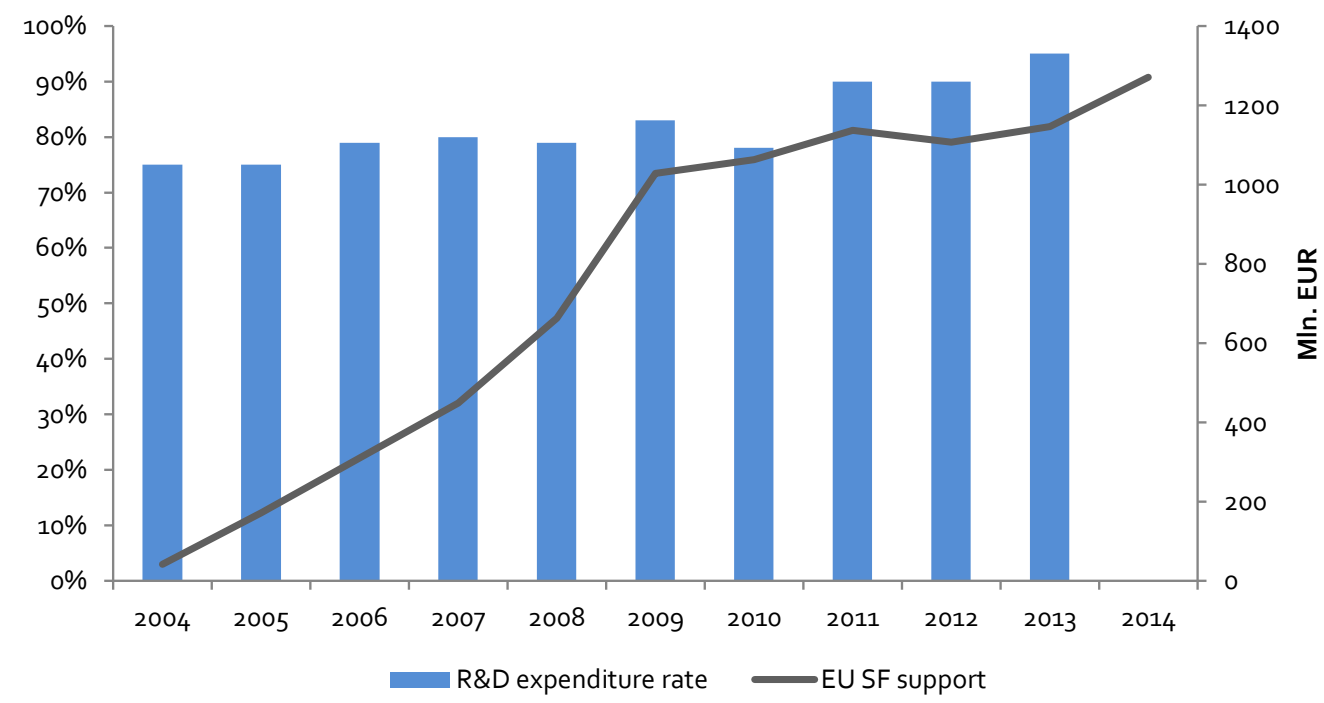

Source: compiled by the authors with reference to the data of Lithuanian Department of Statistics andThe Ministry of Finance of the Republic of Lithuania

Figure 3 shows that R\&D expenditure rate grew by 0.2 percent during the researched period (the data for the year 2014 was not available) and reached its peak of 0.93 percent in 2013. Considering the policy of structural funding in respect of R\&D expenditure, it is presumed that structural funding might have had the impact on R\&D expenditure.

Calculations of Pearson correlation coefficient, estimated to determine the strength of the links between R\&D expenditure and the EU structural support, revealed that the value of $r$ is equal to 0.798 and $\mathrm{p}$ is equal to 0.003 , which proposes that the links between $\mathrm{R} \& \mathrm{D}$ expenditure and the EU structural support are strong positive.

The rate of entrepreneurship in the country is reflected in the number of operating entities - a large number of operating entities is related to favourable business conditions in the country. The dynamics of the EU structural support and the number of operating entities in Lithuania during the period 2004-2014 has been presented in Figure 4. 
Fig. 4: The dynamics of the volumes of the EU structural support and the number of operating entities in Lithuania during the period 2004-2014

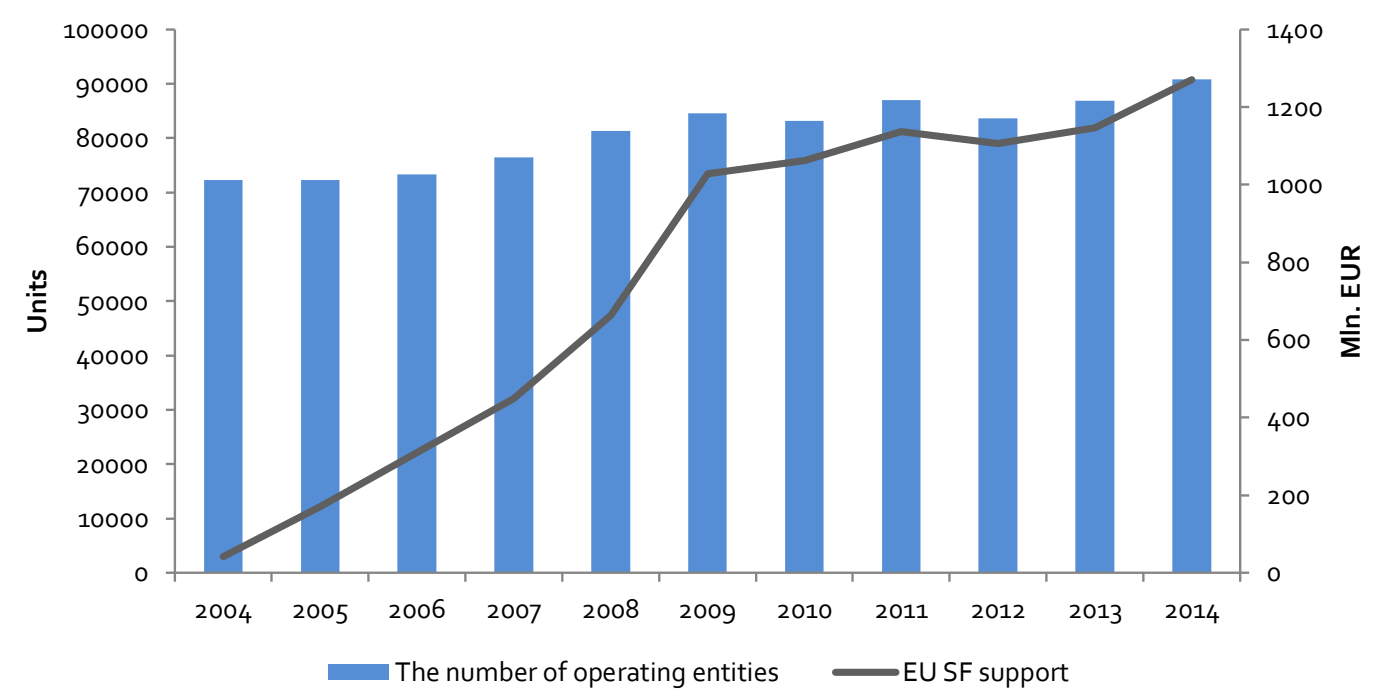

Source: compiled by the authors with reference to the data of Lithuanian Department of Statistics andThe Ministry of Finance of the Republic of Lithuania

Figure 4 reveals that although the number of operating entities changed rather smoothly, with insignificant decreases, in the interval from 2010 to 2014, the indicator shows the obvious general trend of growth, which is likely to have been determined by the EU structural support. Calculations of Pearson correlation coefficient, estimated to determine the strength of the links between the number of operating entities and the EU structural support, revealed that the value of $r$ is equal to 0.861 and $p$ is equal to 0.001 , which proposes that the links between the number of operating entities and the EU structural support are extremely strong and positive. According to statistical data dynamics, it can be stated that the EU structural support has significant impact on the number of operating entities, which confirms that the EU structural support has a positive impact on the growth of the number of operating entities in Lithuania. The research has revealed that the EU structural support has a positive impact on Lithuanian GDP growth, promotes FDI and R\&D expenditure and increases the number of operating entities.

\section{CONCLUSIONS AND DISCUSSION}

The real impact of the EU support on a national economy competitiveness is still disputed (Jurevičiene \& Pileckaite, 2013). According to Andrulevičiūtè (2015) in the 2014-2020 period, Lithuania will receive about 7.2bn euros of support from the EU's Structural Funds and Cohesion Fund. Between 2007 and 2013, the EU's support to the country totalled over 6.9bn euros. After 2020, as the country's GDP is expected to surpass the 75 percent of the EU average threshold, these funds will not be as readily available to Lithuania. Whilst the country could maintain its currently strong economic growth rate, there is also a risk of stagnation.

Findings of the studies (Balzaravičienè \& Pilinkiene 2012) support the EU funding policy objective, oriented towards raising of Lithuanian competitiveness. The change in the EU funding was found to have statistically significant explanatory power over the variance of competitiveness level of tourism and agriculture, forestry and fisheries sectors.

The basic limitations of the research are related to the short data line - since Lithuania joined the EU in 2004, only annual data on the researched issue is available in statistical databases. Thus, the analysis of the quarterly data has not been performed. The analysis proposes which determinants of country's competitiveness have been positively influenced by the EU structural support. Following the empirical research results, the EU structural support has had a positive impact on FDI inflows, GDP growth, the number of operating entities and R\&D expenditure rate during the 2004-2014 year period. 
However, similar research is recommended to be repeated in the course of three to five years because longer data line would enable to achieve higher accuracy whilst evaluating the impact of the EU structural support on the competitiveness of Lithuania.

The impact of the structural support on budget balance, annual inflation, employment rate, CPI and foreign trade balance has not been confirmed because of insufficiently strong correlation between the researched variables. Summarizing the empirical results of the research, it can be stated that, in general sense, the EU structural support promotes the competitiveness of Lithuanian economics.

The results of the research might be helpful whilst implementing the EU Structural Support Absorption Strategy for 2014-2020 and reviewing the opportunities of the support absorption in the fields, where the impact of the support on Lithuanian economics is comparatively weak. The main fields where the efficiency of the support absorption should be increased include business advancement (foreign investment, entrepreneurship), administration of public institutions, labour market and the programmes of economic growth promotion. For sustainable competitiveness of the country, continuity of the successful implementation of competiveness promoting scientific, technological and engineering infrastructure projects must be ensured. Finally, it is important to note that qualitative and efficient improvement of the fields mentioned earlier requires detailed research in strengths and weaknesses of each of the fields.

\section{REFERENCES}

Aiello, F. \& Pupo, V. (2012). Structural Funds and The Economic Divide in Italy. Journal of Policy Modeling, 34 (3), 403-418.

Andrulevičiūtè, V. (2015, September 21). Will Lithuania survive without EU structural funds? Delfi News. Retrieved from http://en.delfi.lt/lithuania/economy/ will-lithuania-survive- without-eu-structural-funds. $d$ ? id=67941614

Balzaravičienè, S., \& Pilinkienè, V. (2012). Comparison and Review of Competitiveness Indexes: Towards the EU policy. Economics and Management, 17 (1), 103-109.

Becker, S. O., Egger, P. H., \& Ehrlich, M. (2010). Going NUTS: The Effect of EU Structural Funds on Regional Performance. Journal of Public Economics, 94, 578-590. doi: 10.1016/j.jpubeco.2010.06.006

Cardenete, M. A. \& Delgado, M. C. (2013). Analysis of The Impact of The European Funds in Andalusia in 2007-2013 Using a General Equilibrium Model. Business and Economics, 4, 448-452. doi: 10.4236/ me.2013.46047

Dall'erba, S., Guillain, R., \& Le Gallo, J. (2009). Impact of Structural Funds on Regional Growth: How to Reconsider a 9 Year-Old Black Box. Region and Development, 30, 77-100.

Dumčiuvienè, D. \& Adomynienè, I. (2014). The Evaluation of European Union Structural Support. Economics and Management, 156, 382-387. doi: 10.1016/j.sbspro.2014.11.207

Enguix, M., Garcia, J., \& Gallego, J. (2012). An Impact Analysis of the Structural Funds on the Variation of the Rate of Employment and Productivity in Objective 1 Regions. European Planning Studies, 20 (4), 685-705.

Fiaschi, D., Lavezzi, A. M., \& Parenti, A. (2011, November 25). Productivity Growth across European Regions: the Impact of Structural and Cohesion Funds. UNIPA. Retrieved from http://www1.unipa. it/ mario.lavezzi/papers/SCF_ProductivityGrowth_spat_05.pdf

Gherghinescu, O., Kolodziejak, A., \& Gherghinescu, G. (2008). Competitiveness of the European Union under the Structural Funds Framework and the Lisbon Agenda. Finance - Challenges of the future, 1 (8), 156-161.
Jurevičienè, D. \& Pileckaitè, J. (2013). The impact of EU structural funds support and problems of its absorption. Business Management and education, 11 (1), 1-18.

Katsaitis, O. \& Doulos, D. (2009). FDI Inflows in The EU-15 and The Role of Structural Funds. International Advances in Economic Research, 15 (4), 488-489.

Lewandowska, A., Stopa, M., \& Humenny, G. (2014). The European Union Structural Funds and Regional Development. The Perspective of Small and Medium Enterprises in Eastern Poland. European Planning Studies, 23 (4), 785-797.

Lithuanian Department of Statistics. (2014, May). The Basic Indicators of The Country. Official Statistics. Retrieved from http://osp.stat.gov.It/ web/guest

Lithuanian Free Market Institute. (2011, April 14). ES struktūrinių fondų lèšų panaudojimas Lietuvoje [Absorption of the EU structural funds in Lithuania]. Analytical Works. Retrieved from http://files.Irinka.It/ analitiniai\%20darbai/ES\%20lesos.pdf

Mohl, P. \& Hagen, T. (2010). Do EU Structural Funds Promote Regional Growth? New Evidence from Various Panel Data Approaches. Regional Science and Urban Economics, 40 (5), 353-365.

Mosionek-Schweda, M. \& Tokarski, M. (2014). The Absorption of The European Funds Granted to Poland for Period 2007-2013 - Examples of Projects and Evaluation. Dialog, 1 (3), 46-51.

Navickas, V. (2010). Konkurencingumo metodologiniai kriterijai ir jy taikymo praktika. Lietuvos ekonomikos konkurencingumas ir socialine sanglauda [Methodological criteria of competitiveness and application of these criteria. Economic competitiveness and social cohesion in Lithuania]. Vilnius: Vilnius Pedagogical University Publishing.

Paun, C. (2013). The Socio-economic Impact of European Funds on Eastern European Countries. International Review of Social Research, 4 (1), 49-56.

Pose, A. \& Fratesi, U. (2004). Between Development and Social Policies: The Impact of European Structural Funds in Objective 1 Regions. Regional Studies, 38, 97-113. doi: 10.1080/00343400310001632226 
Puigcerver-Penalver, M. (2004). The Impact of Structural Funds Policy on European Union's Growth. A Theoretical and Empirical Approach. The European Journal of Comparative Economics, 4 (2), 179-208.

SEE Riga University. (2011). Evaluation of the impact of EU funds on the economy of Latvia. ES Fondi Latvia. Retrieved from http://www.esfondi. Iv/upload/Petijumi_un_izvertejumi/2ndStageReportEnglishUltimateFi nal15Dec.docx

The Ministry of Finance of the Republic of Lithuania (2014, April 03). Detailed Statistics of The Absorption of The EU Support for 2007-2013. EU Support. Retrieved from http://www.esparama.It/barometras

Varga, J., \& Veld, J. (2010). The Potential Impact of EU Cohesion Policy Spending in the 2007-2013 Programming Period: A Model-Based Analysis. Economic Papers, 422, 1-63. doi: 10.2765/43684

Žalevičienè, A. (2012). Regioninè politika ir Europos Sajungos struktūrine parama: patirties ivertinimas [Regional policies and the EU structural support: evaluation of the experience Economics and management: current issues and prospects]. Ekonomika ir vadyba: aktualijos ir perspektyvos, 2 (26), 44-53. 